University of Nebraska - Lincoln

DigitalCommons@University of Nebraska - Lincoln

\title{
STATE-LEVEL APPROACHES TO MANAGING THE USE OF CONTRACEPTIVES IN WILDLIFE IN THE UNITED STATES
}

John D. Eisemann

USDA/APHIS/WS National Wildlife Research Center, John.D.Eisemann@aphis.usda.gov

Jeanette R. O'Hare

United States Department of Agriculture

Kathleen A. Fagerstone

United States Department of Agriculture

Follow this and additional works at: https://digitalcommons.unl.edu/icwdm_usdanwrc

Part of the Life Sciences Commons

Eisemann, John D.; O'Hare, Jeanette R.; and Fagerstone, Kathleen A., "STATE-LEVEL APPROACHES TO MANAGING THE USE OF CONTRACEPTIVES IN WILDLIFE IN THE UNITED STATES" (2013). USDA National Wildlife Research Center - Staff Publications. 1498.

https://digitalcommons.unl.edu/icwdm_usdanwrc/1498

This Article is brought to you for free and open access by the U.S. Department of Agriculture: Animal and Plant Health Inspection Service at DigitalCommons@University of Nebraska - Lincoln. It has been accepted for inclusion in USDA National Wildlife Research Center - Staff Publications by an authorized administrator of DigitalCommons@University of Nebraska - Lincoln. 


\title{
STATE-LEVEL APPROACHES TO MANAGING THE USE OF CONTRACEPTIVES IN WILDLIFE IN THE UNITED STATES
}

\author{
John D. Eisemann, Jeanette R. O'Hare, and Kathleen A. Fagerstone, Ph.D.
}

\begin{abstract}
Several fertility control agents have recently been registered with the U.S. Environmental Protection Agency for management of wildlife or other free-ranging animals. The registration of GonaCon ${ }^{\mathrm{TM}} \mathrm{Immunocon}^{\mathrm{Im}}$ traceptive Vaccine for use in white-tailed deer (Odocoileus virginianus) and OvoControl for use in Canada geese (Branta canadensis) and pigeons (Columba livia) has caused state wildlife and land management agencies to review their regulatory authority over the use of contraceptives in wildlife. As a result, many states are taking steps to ensure legislation or policies are current with emerging technologies. This article examines the various approaches states are taking to regulate the use of contraceptives. Regardless of the final regulatory approach, biological, social, economic, and political implications must all be discussed as this new tool is introduced into the field of wildlife management. Thoughtful consideration of all aspects of wildlife contraceptive use will lead to the development of sound, best management practices for current and future products.

Key words: Birth control, contraceptives, fertility control, regulation, wildlife, wildlife management.
\end{abstract}

\section{BRIEF COMMUNICATION}

Since 1961, fertility control has been discussed as a possible means of managing wildlife populations. ${ }^{1,3,5}$ While fertility control may never be economically or logistically feasible or even desirable for managing large free-ranging populations in the vast American wild lands, shifts in public attitudes shaped by animal welfare concerns are causing wildlife managers to consider nonlethal methods, including fertility control, to manage wild animal populations in urban-suburban settings.

In response to this growing need, advances in research and clarification of regulatory authority ${ }^{2}$ have led to development and registration of four fertility control products for wildlife management. Ornitrol $^{\mathrm{TM}}$ (Avitrol Corporation, Tulsa, Oklahoma 74145, USA), was registered in 1970 by the U.S. Environmental Protection Agency (EPA) for controlling pigeon populations but was cancelled in 1993 as a result of market concerns. OvoControl-G (Innolytics, LLC, Rancho Santa Fe, California 92067, USA) was registered in 2005 for managing Canada geese (Branta canadensis) in urban-suburban areas, and OvoControl-P, was registered in 2007 for pigeon control (Columba livia). While OvoControl-P is proving to be a viable product, OvoControl-G will not be renewed by the registrant because current low sales

From the United States Department of Agriculture, Animal Plant Inspection Service, Wildlife Services, National Wildlife Research Center, 4101 LaPorte Avenue, Fort Collins, Colorado 80521, USA (Eisemann, O'Hare, Fagerstone). Correspondence should be directed to $\mathrm{Mr}$. Eisemann (John.D.Eisemann@aphis.usda.gov). do not support continued registration. The primary cause of poor sales is the extensive regulatory and permitting process required on the label by the EPA at the request of the U.S. Fish and Wildlife Service and state game and fish agencies (Wolf, Innolytics, LLC, pers. comm.). In 2009, GonaCon $^{\mathrm{TM}}$ Immunocontraceptive Vaccine (U.S. Department of Agriculture, Animal Plant Inspection Service [USDA APHIS]) was registered for managing fertility in white-tailed deer (Odocoileus virginianus). Most recently, in 2012, ZonaStat-H (Humane Society of the United States, Washington, D.C. 20037, USA) was registered for use in managing fertility in wild horses (Equus ferus caballus) and burros (Equus asinus asinus).

Fertility control products are subject to multiple layers of regulatory oversight before they can be used in the field. In 2005, the EPA and the Food and Drug Administration (FDA) divided authority over contraceptive use in animals. ${ }^{2}$ The FDA retained authority of products intended for use in livestock, companion animals, and zoo animals. The EPA assumed authority of products used in wild and feral animals. While this decision hastened the entry of wildlife products into the market, it also meant a single product could be registered by either agency depending upon the intended use. GonaCon, for example, is registered by the EPA for use in free-ranging white-tailed deer. However, it could not be used in zoo populations of captive white-tailed deer until reviewed and approved for use by the FDA.

The primary law that the EPA administers when regulating pesticide products, including fertility control agents for use in wildlife, is the Federal Insecticide, Fungicide, and Rodenticide Act (FIF- 
Table 1. Statutory mechanisms available to state wildlife management authorities for regulating the use of fertility control tools in terrestrial wildlife species.

State

Arizona

Connecticut

Delaware

Georgia

Iowa

Minnesota

Missouri

Nebraska

New Hampshire

New Jersey

Ohio

South Carolina
Statutory code specifically identifying the use of fertility control agents in wildlife

12-4-309(B): A person shall not administer any drug to any wildlife under the jurisdiction of the state, including but not limited to drugs, used for fertility control, disease prevention or treatment, immobilization, or growth stimulation without written authorization from the Department or as otherwise provided under subsection (F).1

26-490-26(B): No person may administer any chemical or biological substance, including but not limited to drugs, pesticides, vaccines, or immunocontraceptives or make any physical alteration or affix any device to any free-ranging wildlife without first obtaining a permit from the commissioner.

7-5-556(a): No person or persons shall administer fertility control agents or immunocontraceptives to game birds or game animals except as authorized by a permit from the Director of the Division of Fish and Wildlife in accordance with existing laws and regulations.

27-3-181(B): It shall be unlawful to apply any fertility control to any wildlife, except in accordance with wildlife fertility control permit issued under the provisions of this article and any rules or regulations adopted by the board. Fertility control means any action that results in contraception, contragestion, sterilization or produces a temporary or permanent state of infertility.

11-6-481 A.40: Except with written authorization from the director or the director's designee or as otherwise provided by law, a person shall not administer any drug to any wildlife under the jurisdiction of the departmental of natural resources, including but not limited to drugs used for fertility control, disease prevention or treatment, immobilization, or growth stimulation.

97A.501(3): A person may not administer contraceptive chemicals to noncaptive wild animals without a permit from the commissioners.

3-10-4.110(6): No person shall administer, by any means, any contraceptive or reproductive inhibitor to any species of wildlife outside of captivity in Missouri without written authorization of the Director.

37-258(B): Except with written authorization from the secretary of the commission or his or her designee or as otherwise provided by law, a person shall not administer a drug to any wildlife under the jurisdiction of the commission, including, but not limited to, a drug used for fertility control, disease prevention or treatment, immobilization, or growth stimulation.

28-207:8-C: No person shall administer any drug, including but not limited to drugs used for fertility control, disease prevention or treatment, immobilization, or growth stimulation, to any mammal, bird, reptile, or amphibian under the jurisdiction of the fish and game department without the written authorization from the executive director or his or her designee, except as provided in paragraph III or IV.

7:25-5.37(a): No person shall administer or otherwise employ the use of fertility control materials and/or methodologies including, but not limited to, those which result in contraception, contragestation and/or sterilization to any species of free ranging wildlife without first procuring a permit approved by the Council and issued by the Division under this section. No person shall employ any physical alteration or device that would alter the reproduction potential of any free-ranging wildlife species without first procuring a permit as required. The possession of such unauthorized materials or devices in the field shall be considered the attempt to take wildlife contrary to the provisions of the code....

1531.01(K): The chief shall adopt rules establishing standards and guidelines for the administration of contraceptive chemicals to noncaptive wild animals. The rules may specify chemical delivery methods and devices and monitoring requirements. The chief shall establish criteria for the issuance of and shall issue permits for the administration of contraceptive chemicals to noncaptive wild animals. No person shall administer contraceptive chemicals to noncaptive wild animals without a permit issued by the chief.

50-11-96(A): It is unlawful for a person to introduce a fertility control agent or chemical substance into any wildlife without a permit from the department. 
Table 1. Continued.

\begin{tabular}{|c|c|}
\hline State & Statutory code specifically identifying the use of fertility control agents in wildlife \\
\hline Texas & $\begin{array}{l}\text { 5-61.023: No person may intentionally apply contraceptives to any vertebrate wildlife } \\
\text { resource unless the person first obtains written authorization from the department. }\end{array}$ \\
\hline Utah & $\begin{array}{l}\text { 23-13-19(K): Except as authorized by Subsection (3) or a rule made by the Wildlife } \\
\text { Board, a person may not administer or attempt to administer a substance to protected } \\
\text { wildlife. Substance means a chemical or organic substance that 'controls fertility' } \\
\text { among other actions. }\end{array}$ \\
\hline Virginia & $\begin{array}{l}\text { 5-29.1.1-580.1: Without written authorization from the Director or his designee, it is } \\
\text { unlawful to administer any drug to any vertebrate wildlife, except in accordance with a } \\
\text { permit issued under the provisions of this title or regulations adopted by the Board. } \\
\text { This prohibition shall include, but not be limited to, drugs used for fertility control, } \\
\text { disease prevention or treatment, immobilization, or growth stimulation .... For the } \\
\text { purposes of this section, the term "drug" means any chemical substance, other than } \\
\text { food, that affects the structure or biological function of wildlife species. }\end{array}$ \\
\hline West Virginia & $\begin{array}{l}\text { 20-2-5d: Notwithstanding any other provisions of this code and except as specifically } \\
\text { authorized by the director in consultation with the wildlife resources section of the } \\
\text { division, it is unlawful for anyone to administer any chemical, biological compound or } \\
\text { device to free roaming or noncaptive wildlife for the purpose of fertility control. The } \\
\text { director shall promulgate legislative rules in accordance with the provisions of article } \\
\text { three, chapter twenty-nine-a of this code whereby the director may issue such } \\
\text { authorization. }\end{array}$ \\
\hline Wyoming & $\begin{array}{l}\text { 23-1-302: The commission is directed and empowered: To prohibit and regulate the } \\
\text { administration of any chemical, biological substance or physical procedure to wildlife } \\
\text { under the management and jurisdiction of the commission for the purpose of } \\
\text { controlling fertility or reproduction. }\end{array}$ \\
\hline
\end{tabular}

RA). FIFRA mandates a national review and registration process for pesticides. The EPA reviews products for environmental safety, human health, and effectiveness before they are granted a registration under FIFRA Section 3. A Section 3 registration does not automatically permit product use anywhere in the United States. Each state has its own set of unique regulatory processes a product must undergo before approval for use in that state. This article details the regulatory mechanisms available to states for managing the use of fertility control tools in wildlife.

FIFRA provides states and U.S. territories the authority through local laws and regulations to allow or deny the use of a federally registered pesticide within the state. This authority is normally administered by the State Department of Agriculture. The process varies from routine acceptance of EPA-approved products to a state conducting its own safety and efficacy evaluation tailored to specific conditions found within the state.

Two common regulatory mechanisms under FIFRA do not involve a Section 3 registration but allow uses of a pesticide under specifically defined circumstances. Under Section 24(c) of FIFRA, a state can issue a product registration to address a Special Local Need within its state when a nationally registered product or specific use is unavailable. States also have the authority under Section 18 of FIFRA to use an unregistered product or a registered product for an unregistered use to respond to an emergency within the state. An emergency can be declared to circumvent projected economic losses, to protect threatened or endangered (T\&E) species, to provide animal or plant quarantine, or to protect public health.

Regardless of the state registration process, nearly all states' pesticide registration authorities seek input from the state wildlife management authorities prior to granting a product registration if the product has the potential to affect statelisted T\&E species or other ecologically or economically important species. Contraceptive products intended for use on hunted species are of significant biologic and economic concern for state wildlife management authorities, and, thus, states have weighed in heavily on their use.

Perhaps the oldest U.S. regulation suggesting specific wildlife management was a constitutional amendment adopted in Vermont in 1777. This amendment (Article XXXIX, Constitution of Vermont 1777) granted all citizens of Vermont the right to hunt and fish. This right was codified as a result of recently obtained freedom from 
British rule and from the concept of the King's dominion over all natural resources within the kingdom. Vermont's constitutional amendment established the basis for future wildlife management policies that consider the citizen's right to hunt and fish prior to adopting other management strategies. Since 1996, citizens of 13 states (Alabama, Arkansas, Georgia, Louisiana, Minnesota, Montana, North Dakota, Oklahoma, South Carolina, Tennessee, Virginia, Vermont, and Wisconsin) have approved constitutional amendments granting citizens the inalienable right to hunt. ${ }^{4,5}$ Similar measures were defeated in three states (Arizona, New Mexico, and Texas), and five state initiatives are proposed for vote before 2015 (Idaho, Kentucky, Mississippi, Nebraska, and Wyoming). Two states, Colorado and New Hampshire, have adopted legislation or statutes mandating that the state will utilize hunting, trapping, and fishing as the primary methods of effecting necessary wildlife harvests.

The current desire to obtain a constitutional right to hunt is largely driven by the potential loss of hunting opportunities and revenue. Conversely, in urban and suburban-wild land interfaces local citizens, concerned for their property, personal safety, and the welfare of the animals, are demanding that wildlife management authorities restrict hunting in favor of nonlethal options. Wildlife managers are responding by increasing public education efforts and implementing restricted hunts. Many states are finding this approach successful in limited situations. However, as public pressure mounts, wildlife managers are being forced to consider nonlethal approaches, and many states are facing the prospect of using contraceptive-based approaches.

State wildlife authorities have primary authority over the management of species occurring within their states with the exception of those species regulated by federal law (for example, the Endangered Species Act and the Migratory Bird Treaty). State codes or statutes provide guidance on management authority and implementation of specific management activities, including the legal 'take' of wildlife. Because fertility control techniques are relatively new, until recently state codes have not identified them as legal or prohibited methods of 'take.'

Interviews with state wildlife management authorities and a survey of state codes and statutes have shown that a state's legal ability to regulate fertility control tools falls into two approaches. Some states have begun modifying their codes to specifically include fertility control agents. Other states are relying on existing language to give them authority over these tools. In the latter approach, the language most commonly referenced relates to illegal means of take. Most state code includes a section that carries a message similar to the following: "No person shall at any time make use of any pitfall ... poison, explosive, or chemical for the purpose of injuring capturing, or killing birds or animals protected by law or regulation of this state" (Alabama Code 9-11-245). The inclusion of the word "chemical" or perhaps "drug" or "vaccine" provides the necessary latitude to include fertility control tools, including devices. Another approach taken by many states is to rely on the oversight authority of game or wildlife commissions to regulate the use of fertility control tools and to promulgate rules allowing their use.

While states have traditionally not considered contraceptives or other fertility control agents as viable management techniques, recent advances in fertility control technology, such as those cited above, have led to a growing trend among states to modify their codes. In the mid-1990s terms such as 'contraceptive,' 'fertility control agent,' and 'contragestive' began appearing in state code. Currently 17 states have adopted language that specifically identifies fertility control agents (Table 1) as prohibited means of 'taking' wildlife.

Regardless of the approach utilized to regulate contraceptive use in wildlife, no state absolutely prohibits their use in the field. Every state has provisions in their code or statutes that allow for research under the approval of the Director or Wildlife Commission, including research on contraceptives. States in which there is great public pressure to utilize contraceptives have begun defining the process for permitting this research. Most will require contraceptive use to be predicated on justification for why hunting or other traditional management actions are not appropriate. After that justification is provided, project proposals will be evaluated based on defined objectives and geographic restrictions in a study protocol, adherence to federal and state regulations, strict reporting, and participation of the state wildlife management agency (Perdito, Maryland Department of Natural Resources, pers. comm.).

The use of fertility control agents for managing wildlife is still in its infancy. However, as the U.S. population continues to urbanize, human-wildlife conflicts will escalate. The growing research interest in these agents will lead to greater availability of these tools, and wildlife managers 
will increasingly be asked to incorporate them into their management. With proper regulatory mechanisms in place and an understanding of how to effectively incorporate these tools, fertility control agents will find their niche in modern wildlife management.

\section{LITERATURE CITED}

1. Davis, D. E. 1961. Principles of population control by gametocides. Trans. 26th N. Am. Wildl. Conf. 26: 160-167.

2. Eisemann, J. D., K. A. Fagerstone, and J. R. O'Hare. 2006. Wildlife contraceptives: a regulatory hot potato. Proc. Vertebr. Pest Conf. 22: 63-66.
3. Fagerstone, K. A., M. A. Coffey, P. D. Curtis, R. A. Dolbeer, G. J. Killian, L. A. Miller, and L. M. Wilmot. 2002. Wildlife Fertility Control. Wildl. Soc. Tech. Rev. 02-2, 29 p.

4. Shinkle, D. 2011. State constitutional right to hunt and fish. National Conference of State Legislators. www. ncsl . org / issues - research/env-res/state-constitutionalright-to-hunt-and-fish.aspx. Accessed 20 July 2012.

5. Warren, R. J. 1995. Should wildlife biologists be involved in wildlife contraception research and management? Wildl. Soc. Bull. 23: 441-444.

Received for publication 24 August 2012 